\title{
Paradox of the Sense of Time
}

\author{
Suna Luo \\ English Language College of Qingdao University of Science \& Technology \\ 69 Songling Road,Laoshan District, Qingdao 266061, China \\ E-mail: suna-luo@hotmail.com
}

\begin{abstract}
In a study of Gatsby it is found that "time" is the trigger to reveal the myth of Gatsby. This paper aims to explain how time figures itself as a paradox in the greater context of the novel. Time, in its most general lexical meaning, is a continuous measurable condition from the past through the present and into the future. In Gatsby, Fitzgerald evokes a feeling of restlessness of time, which leaves the main character in a state where divisions between periods of time are so vague as if past, present and future were congealed into one condition. Concurrent with this condition, Fitzgerald treats time with the effect of simultaneous detachment and involvement. Through Fitzgerald's manipulation of time, the reader can see a mysterious connection between Gatsby, the protagonist of the story and Nick Carraway, the narrator of the story. Gatsby's story, the core of which is to bring the past into the future, has parallels to Carraway's experience. With not fewer combinations of opposing ideas and facts, the novel is distinguished with conflicts and paradoxes, which is based upon the concept of time, suggesting some intricate themes.
\end{abstract}

Keywords: Gatsby, Paradox, Sense of time

The sense of time, which the advanced Western countries have been involved with since the Renaissance period, is considered as a distinctive feature in the twentieth-century literature. ${ }^{12}$ Ricardo J. Quinones, in Mapping Literary Modernism, makes a profound study of the literary flowing of the age, whose historical center of gravity extends from 1900 to 1940, the decade prior to World War I into the early years of World War II. Quinones charts Modernism's departure, which is the "time-complex" inherited from the Renaissance, and traces its course of development. He records the "given" of the Modernist's time and their experience, and points out its destination, which is "something of a pullback, / a revived sense of the reality of history, of the event and of time itself"(Quinones, 1985, pp. 9-11). Quinones' research provides us with appropriate footnotes to The Great Gatsby as well as to any other works of the "high" Modernists.

As with other Modernists, a kind of double dialectic operates in Fitzgerald whereby sets of terms receive twofold evaluations. Gatsby's sense of time is as acute as it is ambiguous. By means of dualizing the versions of time and morality - the center of gravity of the novel-Fitzgerald experienced a transformation of recapture of the past into the transcendental discovery of realities of the present. Paradox of time is effected through an objective depiction of the scenes and a subjective initiative embedded in the characters' view of time.

\section{A state in flux and in stagnancy}

To heighten the consciousness of time, Gatsby presents a sense of continual, restless movement of time. Fitzgerald makes a fragmented arrangement of time in Gatsby's structural narrative. Nick Carraway comes East in the spring of 1922 and finds "great bursts of leaves growing on the trees, just as things grow in fast movies"(Fitzgerald, Penguin Books, 1950, p.10). Time seems accelerated. The scenes, in which are set the principal backgrounds of the three distinctly separate social spheres, move quickly through the three opening chapters: Nick's social call by his cousin Daisy's invitation, where he meets Jordan Baker, a charming girl rumored to have been a golf champion with dishonesty; Nick's observation of the valley of ashes from where the omniscient blind eyes are brooding over, which is a transition from great wealth to bare subsistence; and Nick's experience at one of the fabulous parties given by his neighbor Great Gatsby. Nick narrates the story of Gatsby with time moving forward like movies, suggesting only a vague vision of Gatsby. At the Plaza Hotel in Chapter IV, the forward movement of time is interrupted by a brief change of narrators and a dropping back in time, as Jordan Baker relates the events of October 1917, when she witnessed a fragment of the affair between Daisy and Gatsby. Then pass the scenes where Gatsby reunites with Daisy, with whom he had been in love in 1917 before her marriage with Buchanan; where Gatsby gives a show-off party that Daisy and her rich and burly 
husband Tom attend; where the car is driving towards death. Each scene seems like a peak of a wave and in between the scenes there is a flash-back, a narration of the past that appears like a valley between waves. After the reunion is Nick's narrative of Gatsby's notoriety; the story of James Gatz's past spread around by those who have accepted his hospitality. After that beautiful but garish party, Nick narrates Gatsby's recall of Louisville and an autumn night when Daisy becomes the embodiment of his naïve dream. The death of Myrtle, who is Tom's mistress, is followed by a retelling of Gatsby's first meeting with Daisy. Waves follow valleys, valleys follow waves and there in forms the continual movement of time. The continual agitated motion of the sea is an apt metaphor for the unsettled and restless nature of their society.

The continual movement of time can be felt not only in its structural connection but in some particulars as well. Robert Emmet Long calls it "the miniaturized effect" (Long, 1979, 140) in his study of Gatsby. Using the miniaturized effect, Fitzgerald reinforces the sense of movement. At Gatsby's first party, a large orchestra plays Tostoff's "Jazz History of the World". In this "tossed-off" scrambling of time and experience, "the medium of existence is motion"(Ibid) A guest list in chapter IV is another example. The list is written down by Nick on the empty spaces of a time-table. "It is an old time-table now, disintegrating at its folds, and headed 'This schedule in effect July 5th, 1922'." The names suggest almost no personal distinctness - all cacophony and oddity — as ephemeral as time itself. Another particular that reacts the unsettled and restless nature of the time further is an attention to vehicles throughout the novel. Hydroplanes, yachts, sailboats, ocean liners, automobiles, commuter and continental trains help create the idea of movement of time and motion. Even the clothes Tom wears (riding clothes) are associated with movement. That many of the characters are identified with their cars only reinforces this idea.

The continual movement is absolute and the way in which it flows is also absolute. Everything, except dreams, is surely bound by time. Time flows in one-way without turning back just as we cannot unscramble an omelet or burned wood. Nick knows this law of nature clearly. "You can't repeat the past," he warns Gatsby. Robert Lan Scott expresses the phenomenon with the second law of thermodynamics. The law observes that entropy, the measure of the unavailability or disorganization, is increased by any transport of heat within the system (OED, entropy) or in Scott's words, "entropy increases as time goes by." Scott finds that the law is made concrete in Gatsby. He illustrates that Gatsby proves in three ways that those who want to save hopeful moments and chances now lost in flowing time from entropy of confusion, death can only get entropy (Scott, 1975, pp.81-82). Time's one-way flow is irreversible. Money and dreams are not enough to alter it.

The Great Gatsby's world is built like Gatsby's boat-like house in a circumstance of continual, restless movement of time, nevertheless, its inhabitant does not seem to develop with the flow. Fitzgerald takes pride in recording his generation, his society, his time, which is the synthesis of unsettledness, restlessness and vitality, but he constructs a halt in time's movement that stops the character and confines it to the time passed. In the aspect of time, Gatsby's another side of the dualized vision is a static state of time parallel to the state in flux. In the scene of Gatsby's reunion with Daisy, Ewing Klipspringer plays the hit tunes of "The Love Nest" and "Ain't We Got Fun?" on piano and the words in the latter: "In the meantime / In between time-" (102; ch.V), suggest an emptiness in time. The past is revealed like dreams in fragmented narratives and the present is exposed as a vulgar reality. Then, what is that in-between time? There appears a hole of five years in time's continual movement and Gatsby remains in that hole, the static state between the very start point and time now. It is static, because it does not seem that the five years belong to the continual movement of time which the nature of the book has presented. Man cannot stop time, but man can cut time off. The cut-off of that five years disappears from Gatsby's social life and becomes a separated water in which the unknown young man keeps a part of the past for himself. Fitzgerald doesn't permit the narrators to describe that mysterious part of Gatsby's life. He intends to make those five years a vacuity that traps the main character: The past is extending to the present and time now seems to melt into five-years-ago, with those five years somehow deleted.

Another fact is that time in flux breaks bounds of the sun and the moon, constringing the past and present, night and day into one state. When Gatsby first encounters Daisy at Nick's house, they are so nervous as to be stiff. "Luckily the clock took this moment to tilt dangerously at the pressure of his head, whereupon he turned and caught it with trembling fingers and set it back in place" $(93 ;$ ch.V), as if their meeting sets the clock back to the time when Gatsby possessed Daisy five years ago. "'It's an old clock,' I told them idiotically. I think we all believed for a moment that it had smashed in pieces on the floor" (93; ch.V). Nick announces a moment in stagnancy, not as a recapture of the past but as a repeat or a stretch of that, since it is still that "old clock". When they imagine that the clock, which has recorded the old time, is smashed into pieces, so is the hole of five years. The situation is that as if momentary time stood still. Kenneth Eble has noticed the static state is based on time confusion. He says that Chapter V, being at the center of the novel, "is the most static in the book.... Gatsby holds past and present together"(Eble, 1964, p.323). Time confusion arouses, so does nature's order. Some critics point out that Daisy is allied with Day. For instance, Stallman exemplifies Daisy's identity with day and sunshine in his another essay that demonstrates Gatsby's time theme (Stallman, 1955, pp.59-62). Daisy rejects the four candles prematurely lighted when sunset glows upon Buchanan's porch. At Myrtle's place, Tom smashes Myrtle's nose because she screams hysterically "Daisy! Daisy! Dai-" (43; ch.II). Daisy that represents Gatsby's dream 
of beauty and wealth turns into Day, in opposition to Night when man dreams. Thus the circumstance confuses those who dream. To deliver further this paradoxical ambience to the novel, Nick mentions Gatsby's day-in-night parties where "the lights grow brighter as the earth lurches away from the sun" (46; ch.II). Gatsby is often seen and imagined by Nick to be left in the moonlight: Gatsby's emotional and intellectual state.

Gatsby's story achieves the form of intellectual intensity, the result of the radical movement of time. The scenes change so fast like movies, but the characters are not developed. They are relatively ideographical figures in the time flow. Not only is Gatsby treated as a vague figure who grows only in the understanding of the narrator, but others as well are treated "as if they were ideographs"(Trilling, 1945, p.20). Using this method of economy, Fitzgerald delivers the wealthy and brutal Tom, surprisingly haunted by his "scientific" vision of the doom of civilization, the dim Wolfsheim, the man who fixed the World Series of 1919, and the "valley of ashes" surveyed by the eyes of the oculist's advertising sign. Most of all, the method casts an air of mystery over Gatsby.

The paradoxical conditions of time presented in temporal time and spatial time, time in flux and in stagnancy, serve as an objectivity well equipped for the subjective consciousness of time. In face of confused time, the characters are provided with a subjective initiative to deal with time.

\section{An effect of simultaneous involvement and detachment}

Having absorbed nourishment from Modernists, Fitzgerald is labeled as the spokesman of the time. His sense of time-complex commits Gatsby to time, meanwhile his historical consciousness functions to search after timelessness, a transcendence over the spatial time. Trying to hold the two together, Fitzgerald treats time with a paradoxical effect of simultaneous involvement and detachment.

There is an inescapable sense of time permeated in the novel. Nick, whose narratives vein Gatsby's story, is wary of emotional expression, but haunted by the inevitability of time. Nick remembers that the Buchanans' party is held in early June, because Daisy refers to the longest day. He narrates that Myrtle's death happens in early September when it is too hot, and Henry C. Gatz comes to Gatsby's funeral. He tells us he leaves the East after shaking hands with Tom in late October. Nick represents the traditional moral of the American middle class. He needs regularity in his life. His schedule for the study of bond, his keeping the old clock, his writing of a list of the guests in Gatsby's party on a time-table, all these indicate Nick's dependence on time. It is significant that the old clock, on the edge of being broken by Gatsby, belongs to Nick. Nick is fated to continue committing himself to the clock, the "conscientious hour" (63; ch.III), though he is attracted by Gatsby's romantic dream. There is another schedule, which is made by young Gatz and has been preserved for sixteen years by his father. Stephen Matterson points out: Nick and Gatsby's father obey time, because they have recognized that time cannot be defeated and that they preserve what would otherwise be forgotten (Matterson, 1990, p.55). Yes, Nick and Henry Gatz obey time, while Gatsby disobeys time. But Gatsby also preserves the old thing - that old dream for five years. It is because there exists in these old things a promise for future. The old clock is associated with the regularity of the middle class. Nick possesses it because it gives him promise that he can retreat to his safe and comfortable middle West, where he wants "the world to be in uniform and at a sort of moral attention forever" (8;ch.I). When Gatsby's father shows Nick his son's schedule, he is proud that "Jimmy was bound to go ahead. He always had some resolves like this..." (180; ch.IX). Gatsby preserves his old romance, for the nature of his love transcends the object of that love and what really attracts him is a promise beyond that love. The reason why they preserve something old, something that would otherwise be forgotten is that some promise for future is held in them.

The Americans are frivolous - Fitzgerald shows it cynically. Everyone clutches at the small score of years, flowing with time of jazz and cocktails, which presented an American demeanor, youthful, frank, uncommitted and quick, with the extremes of high-spiritedness and glum disappointment. Everyone is restless, everyone is looking for fun - the post-war reactions. The Buchanans, with the sundials on their lawn, are absolutely obedient to time's passing. They and many uninvited guests at Gatsby's jazz-and-cocktail parties indulge themselves in every beautiful, youthful, joyful moment. They sometimes find themselves empty, but they do nothing, only waiting "for the longest day of the year and then miss it" $(18$; ch.I). Those who intend to rebel against clocks, like Gatsby, who had been obedient to time before he was taken to Daisy's house, and like Myrtle, who waited in Ash-Valley for ten years, are doomed to destruction.

For Gatsby, the past is more than the source of the present; it is the womb to conceive dreams for the future. Confusions with time make him fail to distinguish the future from the past. The past is immortal, that equals to the present, even to future. In Kermit W. Mover's words, "the future has become simply an avenue leading back to the past—or, more specifically, leading back to the glittering possibilities the past once seemed to offer"(Moyer, 1972, p.34) In spite of defying time's one-way flow, Gatsby is forced to mind time while confronting its realities.

'And she doesn't understand,' he said. 'She used to be able to understand. We'd sit for hours-'

He broke off and began to walk up and down a desolate path of fruit rinds and discarded favors and crushed flowers.

"I wouldn't ask too much of her," I ventured. "You can't repeat the past." 
"Can't repeat the past?" he cried incredulously. "Why of course you can!"

He looked around him wildly, as if the past were lurking here in the shadow of this house, just out of reach of his hand (117;ch.VI).

He finds himself at a loss for Daisy's insensitiveness after those five years. Gatsby, nevertheless, always refuses to accept the fact that his early dreams are worthy of nothing. Daisy used to be an extraordinary "nice" girl, Nick judges, only because Gatsby "didn't realize just how extraordinary a 'nice' girl could be" (155; ch.VIII). Nick understands that Gatsby was betrayed by his illusions. Even at the very beginning what overwhelmed Gatsby was his awareness "of the youth and mystery that wealth imprisons and preserves, of the freshness of many clothes, and of Daisy, gleaming like silver, safe and proud above the hot struggles of the poor" (155-56; ch.VIII). Gatsby is eventually forced to accept the inevitability of time. His involvement in time differs from that of Nick. Nick is involved in the routine of time, the principals of time. While Gatsby, being forced to care about time, is involved in the lost five years which have become a gap dividing time into a promising past and a corrupt present. Gatsby tells Nick his consciousness of it.

"His life had been confused and disordered since then, but if he could once return to a certain starting place and go over it all slowly, he could find out what that thing was... " (117; ch.VI).

In order to reinstate the past in the future, Gatsby has arranged for five years. In imagination, he wants to recapture the past; in actuality, he desires to repeat the past. "I'm going to fix everything just the way it was before"(117; ch.VI). Gatsby says. Moyer gives a penetrating comment on the substance of Gatsby's quest: What he wants to recapture is not only Daisy, but the very Daisy "as she was five years ago, before she married Tom Buchanan" and "the ecstatic instant when she suddenly embodied for him all of life's wonder and possibility"(ibid).

In taking an attitude of involvement in time, Fitzgerald gives a consciousness of detachment from time. The effect is embodied in Nick's objective distance of time's movement and Gatsby's sense of timelessness. Nick, though he is the person who involves most in time, gives a relative point of view in his "within and without" position. Nick is "within and without, simultaneously enchanted and repelled by the inexhaustible variety of life" $(42 ;$ ch.II). The ability to be both "within and without" qualifies him as a fair narrator. Critics such as Troy think it one of the great achievements of the novel:

But in Gatsby is achieved a dissociation, by which Fitzgerald was able to isolate one part of himself, the spectatorial or aesthetic, and also more intelligent and responsible ... from another part of himself ... (Troy, 1945, pp.189-90).

Nick's judgment is based on this ability. Being within, he gives an exhaustively revelatory account of the waste land, where the rich are uncommitted and careless, and the Wolfshiems have made chances by every means. Being without, he discovers the spiritual ideal land, which is built on the waste land. Through dislocation of time in narrative, Nick, taking the place of god's eyes, observes mythic, immaterial Gatsby and humane, real Gatsby. His being distant about time's movement shows his realistic attitude to time.

As mentioned above, Gatsby is different from Nick. His attitude toward time is something like negativism in psychology, but like positivism in philosophy. Recognizing that time has changed Daisy-who used to, but now does not understand him - Gatsby utters the famous words quoted above, showing his anxiety about time, simultaneously suggesting his very denial of history. Gatsby is assigned to devote his life to the project of mending the clock, which he did in his childhood to make the most of time and continues in his youth to fix time and to reinstate the past in the present. The problem is time in between, during which there were things between Daisy and Tom that Gatsby would never know, during which Gatsby's life was confused, disordered and corrupted. That is why he wants that time to be wiped out forever, "Just tell him the truth-that you never loved him —and it's all wiped out forever" (138; ch.VII) There are multiple folds of paradox in Gatsby's vision of time. It lies in: Gatsby is involved in mending the clock and resetting it in that instant of the past, but this involvement leads to transcendentalism to neglect time and to deny history; his transcendentalism is revealed as a circle, since it seeks to recapture and freeze that moment in the past. However, by embracing the future. In mending the clock, Gatsby desires to transcend time and reality through recapturing the past and canceling out the present.

The effect of simultaneous involvement and detachment, allied with atmospherical conditions of time, constructs the intersection of timelessness and time, where man examines oneself and identifies a real self with a point of time. It is a process of rediscovery of the reality of self. Gatsby's main concern, like that of The Waste Land, "is to achieve a convincing portrayal of the self as it exists in the one moment of its present consciousness"(Lynen, 1969, p.345).The one moment of self's present consciousness means the reality of self, the human experience in limited spatial time that is a drop of the eternal time. Gatsby desires to find the real self through moral judgment, using the scale of time, the moment of an immediate present and that of a transcendental eternity.

Fitzgerald, announcing himself the spokesman for the Jazz Age, had a high sensitivity to time, especially to time passing, like the other Modernists. In The Great Gatsby, which is deeply concerned with time, we feel Fitzgerald's desire to discover human worth adequate to his time. Confronting all the confusions as the aftermath of the war, the 
author was in a dilemma whether to identify himself with the present when human worth is measured by wealth, or to preserve the traditional value which represents the past. The conflict between the past and the present, and between the reality and the ideal reflects Fitzgerald's outlook of the world, which is a contradiction between romanticism and cynical realism. Fitzgerald tried to dissolve the contradiction by keeping in balance the two ideas, since he believed that "the test of a first-rate intelligence is the ability to hold two opposed ideas in the mind at the same time, and still retain the ability to function"(Fitzgerald, Vol. III, p.388)

As a proof of this ability, Fitzgerald succeeds in expressing a double-visioned self in Gatsby with honesty of imagination. In his introduction to the Modern Library edition of The Great Gatsby in 1934, Fitzgerald says that the easy judgment excised in Gatsby "had nothing to do with criticism but was simply an attempt on the part of men who had few chances of self-expression to express themselves" (Fitzgerald, 1934, pp.108-09), and that the expression is an intimate exploration of a young writer who has lived deeply in the world of imagination and has a pride akin to a soldier going into battle alone (ibid). Then in "The Crack-Up" of 1936, he writes:

I had a strong sudden instinct that I must be alone. I didn't want to see any people at all. I had seen so many people all my life - 1 was an average mixer, but more than average in a tendency to identify myself, my ideas, my destiny, with those of all classes that I came in contact with (Fitzgerald, Vol. Ill, p.390).

These are the expressions of the romantic egotism, which is so celebrated in his first novel, This Side of Paradise. But a more important fact is that there is a maturity in Gatsby, as he sees the limitation of the romantic egotism which, however, he remains faithful to. Holding two minds together in the same time, Fitzgerald expresses his romanticism through Gatsby, the hero breaking up the time's limit in order to find the self's identity in time; simultaneously, he lets Carraway, another aspect of himself, judge the material world with his cynical realism and measure Gatsby's conduct with a clear consciousness of time. Gatsby, as David Parker discovers, is depicted as the hero of the synthesis of the two types: "an idealist, loyal to some transcending object", but he is compelled by circumstances "to explore his own being, to discover, and perhaps to modify, his own identity"(David Parker, 1973, p.29). Carraway is another sort of hero, whose experience of morality is advanced as much as to discover a human value in time of sterility, and in the meantime, to retain the ever-present awareness of man's mortality.

To express the two opposed ideas in the same time, the man of the first-rate intelligence presents conflicts and paradoxes, which put a remarkable construction upon his view of life. Paradox of time gives the explanation for his ambivalence to time, which is a desire to escape from time, but also an attachment to it. In searching for a new moral style in time of uncertainty, he renders the paradoxical moral judgment through a self scrutiny and shows the paradoxical discovery as well. The capacity for romantic wonder, for faith, embodies a human value, which invests meaning in life. But, it is just the same qualities that blind man and divest man's life of meaning. Giving a revelation to the paradoxical relationship between love and wealth, he delivers his tragic sense through the witness of the tragic hero Gatsby whose pursuing illusions rooted in the past and self awareness of it evoke our pathos, but in terms of the tragic hero himself, it is the loss of the illusions that casts the tragic over the novel. From all the paradoxes of the concepts presented in Gatsby, the final paradox that Gatsby's self-destruction leads to his self-fulfillment, is realized by Carraway, in whom the real pathos resides.

Nietzche had a famous saying, "Truth has never yet hung on the arm of an absolute". Living in a time of uncertainty when traditional beliefs and absolute standards have disintegrated, and give way to relativism, man has to search for a new set of values and make sure of his new identity with time. It is the impulse to discover an identity in eternities of time that tunes the theme song of Gatsby. Nevertheless, the great composition reaches a climax when Gatsby's failure of self-discovery realizes the fulfillment of Carraway's self-discovery. The new value Carraway discovers in Gatsby actually has its root in their old warm world. Carraway's discovery, which provides the whole story of Gatsby with a paradox, is concluded in the ending of the novel: not only the corrupt Gatsby, but the absurd Gatsby who desires to repeat the past as well, "turns out all right at the end" $(8 ; c h . l)$, because "we beat on, boats against the current, borne back ceaselessly into the past" $(187 ;$ ch. $I X)$.

\section{References}

\section{Primary Sources}

Fitzgerald, F. Scott. (1950). The Great Gatsby. England: Penguin. (All page references to The Great Gatsby will be from this edition)

Fitzgerald, F. Scott. (1960). The Crack-Up. The Brodley Bead: F. Scott Fitzgerald, ed. Cowley, Malcolm. Vol. 3, 273-410. London: The Bodley Head.

Fitzgerald, F. Scott. (1963). The Letters of F. Scott Fitzgerald, ed. Turnbull, Andrew. New York: Scribner's.

Fitzgerald, F. Scott. (1970). An Introduction to The Great Gatsby. Fitzgerald's The Great Gatsby, ed. Henry Dan Piper. New York: Charles Scribner's Sons. 


\section{Secondary Sources}

Eble, Kenneth. (1964). The Craft of Revision: The Great Gatsby. American Literature, Vol. XXXVT, Wo. 3. Nov., pp. 315-326

Long, Robert Emmet. (1979). The Achieving of The Great Gatsby: F. Scott Fitzgerald, 1920-1925.London: Associated UP.

Matterson, Stephen. (1990). The Critics Debate: The Great Gatsby. London: Macmillan..

Moyer, Kermit W. (1991). The Great Gatsby: Fitzgerald's Meditation on American History. (Fitzgerald / Hemingway Annual 1972). Gatsby. ed. Harold Bloom. New York: Chelsea House.

Parker, David. (1986). The Great Gatsby: Two Versions of The Hero. Gatsby, ed. Harold Bloom. New York: Chelsea House.

Piper, Henry Dan. ed. (1970). Fitzgerald's The Great Gatsby: the Hovel the Critics, the Background. New York: Scribner's.

Quinones, Ricardo J. (1985). Mapping Literary Modernism. New Jersey: Princeton UP.

Scott, Robert L. (1991). Entropy vs. Ecology in The Great Gatsby. Gatsby, ed. Harold Bloom. New York: Chelsea House.

Stallman, R. W. (1955). Gatsby and Hole in Time. Gatsby, ed. Harold Bloom.

Trilling, Lionel. (1985). F. Scott Fitzgerald. F.Scott Fitzgerald, ed. Harold Bloom. New York: Chelsea House.

Troy, William. (1951). Scott Fitzgerald - the Authority of Failure. F. Scott Fitzgerald, The Man and His Work. ed. Alfred Kazin. New York: Collier Books. 